\title{
UMA DISCUSSÃO DO PROCESSO DA URBANIZAÇÃO BRASILEIRA, POLÍTICAS PÚBLICAS E O DESENVOLVIMENTO DO ESPAÇO HOTELEIRO
}

\author{
Lincoln Augusto Taddeo Firoozmand ${ }^{1}$ \\ Sandra Maria Fonseca da Costa ${ }^{2}$
}

Resumo: O presente trabalho busca discutir o processo de urbanização brasileira e as suas relações com as políticas públicas e a expansão do parque hoteleiro. A intensificação da urbanização no Brasil constituise de um fenômeno da segunda metade do século XX. As suas características manifestam-se de diversas formas, muitas vezes com o incentivo de políticas públicas que favorecem o investimento do capital privado como, por exemplo, o Plano Nacional de Desenvolvimento (II PND). Dentro desta temática pretende-se compreender como a urbanização brasileira atrelada às políticas de desenvolvimento favoreceram o surgimento do espaço hoteleiro. Ressalta-se a discussão sobre a relação entre o Plano Nacional de Desenvolvimento (II PND) e o favorecimento do investimento do capital privado hoteleiro, além de uma apresentação de dados estatísticos do número de estabelecimentos de hospedagem e o número de unidades habitacionais, segundo as principais capitais do território brasileiro.

Palavras-chave: Urbanização; Políticas públicas; Desenvolvimento; Hotelaria.

\footnotetext{
1 Mestrado em Planejamento Urbano e Regional/Universidade do Vale do Paraíba, Brasil. E-mail: lafiroozmand@faap.br.

2 Mestrado em Planejamento Urbano e Regional/Universidade do Vale do Paraíba, Brasil. E-mail: sandra@univap.br.
} 